\title{
巨大気腫性肺囊胞に対する 囊胞内吸引療法後のブラ切除の経験
}

青木 正, 広野 達彦

\section{要旨}

Hugh-Jones V 度の呼吸困難を自覚する巨大気腫性肺囊胞患者に対して, 霊胞内吸引療法後に囊胞切 除を安全に施行し得た 2 症例を経験した. 症例 1 は左中下肺野のブラに対して, 症例 2 は右上肺野のブ ラに対して吸引療法を行った。囊胞内吸引療法により呼吸状態の改善が得られたが, 症例 1 では再膨張 性肺水腫, 症例 2 では肺炎を併発した. これらの合併症が軽快した後に胸腔鏡併用小開胸による褰胞切 除を施行した．開胸術後の合併症はなく，2症例ともに必要酸素量の減少と自覚症状の改善を認めた. 本邦の囊胞内吸引療法に併用する治療は, 襄胞内癒着療法が多く報告されている. しかし胸腔鏡手術の 普及, 開胸方法の工夫などにより低侵壟手術が可能となり，併用治療として開胸手術も選択肢として考 えられた．䨣胞内吸引療法後に開胸手術を施行した本邦例と共に報告する.

索引用語：巨大気腫性肺囊胞, 胸腔鏡下手術, 囊胞内吸引療法 emphysematous giant bulla, video-assisted thoracic surgery, intracavitary suction

\section{はじめに}

巨大気腫性肺囊胞症の外科治療は, 呼吸困難 合併例や頻回の感染などの有症状例には効果を もたらすことが知られている，呼吸困難のある

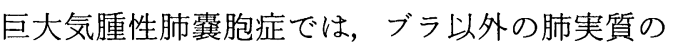
変化による症状を有している場合があり ${ }^{1)}$, 著 しい低肺機能患者では手術適応となることはな かった. しかし低肺機能症例でも囊胞内吸引療 法により，呼吸困難を改善できることが報告さ れている ${ }^{2-7)}$. 今回我々は, Hugh-Jones V 度の 呼吸困難を自覚する巨大気腫性肺囊胞患者に対 して, 虽胞内吸引療法を施行し全身状態を改善 させた後に, 震胞切除を安全に施行し得た 2 例 を経験したので，本邦報告例とともに報告する.

\footnotetext{
国立療養所西新潟中央病院 呼吸器外科

原稿受付 2000 年 3 月23日

原稿採択 2000 年 7 月 5 日
}

症例

症例 $1 ： 60$ 歳, 男性.

契煙歴：40本 $\times 40$ 年.

既往歴：45歳時脳梗塞, 54歳時右自然気胸.

現病歴：1990年より体動時の息切れを自覚し ていた. 1992年の右自然気胸発生を契機として 近医で肺気腫, 肺囊胞と診断された. 1994年か ら在宅酸素療法を導入され，1998年になり体動 時の呼吸困難が強くなったため, 肺気腫に対す る外科治療を希望し, 当院を紹介受診した。

現 症: 身長 $168 \mathrm{~cm}$, 体重 $40 \mathrm{~kg}$. 胸郭はビア 樽状, 呼吸は20回/分で呼吸音は両肺野で減弱し ていた. 安静時でも酸素 $3 \mathrm{l} / \mathrm{min}$ を必要として いた. Hugh-Jones V 度であった。

入院時検査成績: 安静時の酸素 $3 \mathrm{l} / \mathrm{min}$ 吸 入下の動脈血ガス分析は, Table 1 に示した.

胸部レントゲン写真及び CT：肺野は全体に 気腫性変化が著しい. 左中下肺野に巨大肺囊胞 があり，残存肺を圧排している（Fig. 1-a，b). 


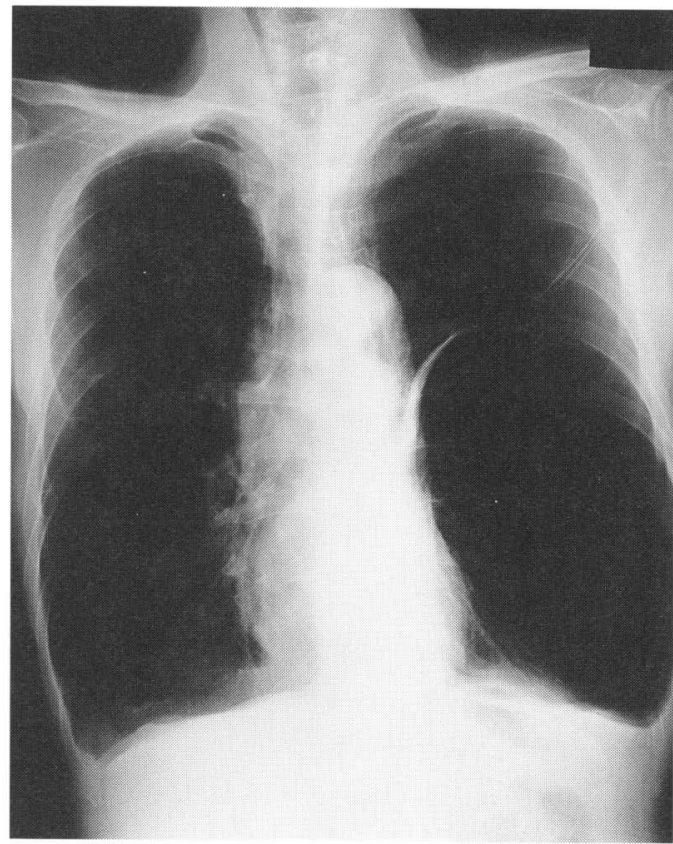

Fig. 1-a Chest $\mathrm{x}$-ray on admission showed giant emphysematous bulla in the left thoracic cavity.

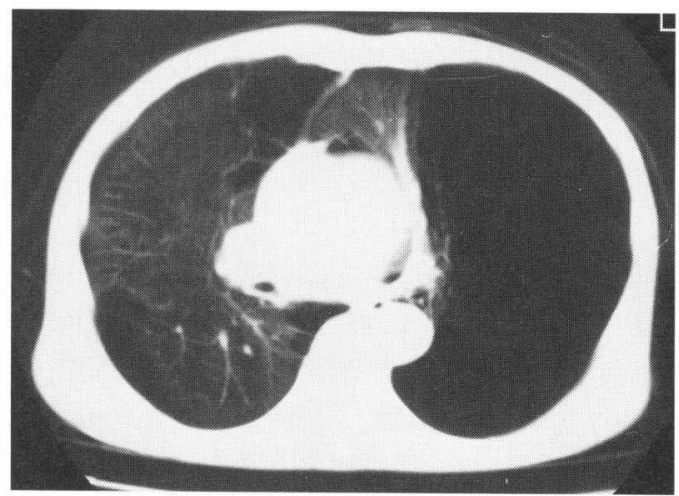

Fig. 1-b Chest CT scan showed giant emphysematous bulla and decompressed lung parenchyma in the left thoracic cavity.

入院後経過：1998年 9 月 18 日に入院した。 ず呼吸りハビリテーションを開始したが，呼吸 苦が強く効果は上がらなかった。 しかし肺囊胞 切除により残存肺の拡張が得られれば, 呼吸困 難の改善に繫がると判断された，全身状態不良 であったため, まず囊胞内吸引で残存肺の拡張 程度と呼吸及び全身状態の改善を観察すること
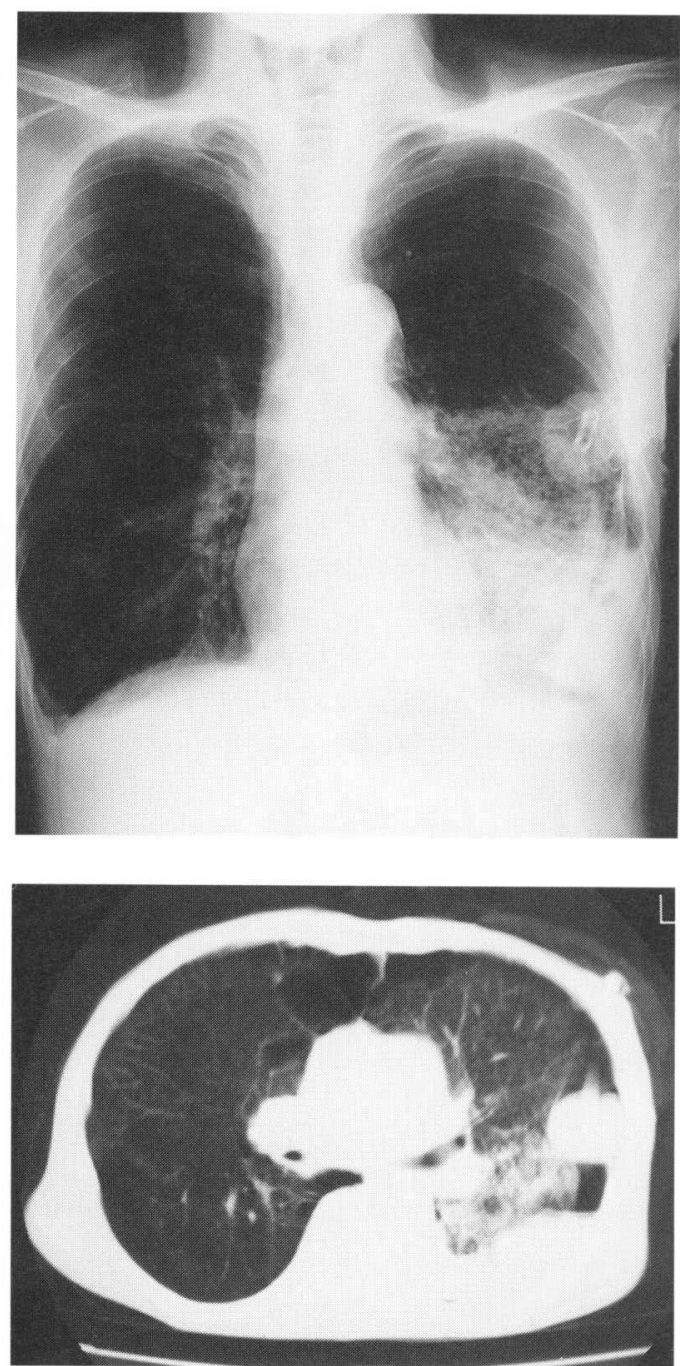

Fig. 1-c, d Chest $\mathrm{x}$-ray and CT scan showed the re-expansion pulmonary edema and pleural effusion after suction of the giant emphysematous bulla.

にした. 10月19日肺囊胞内にフォーレカテーテ ルを留置した。 まず局所麻酔下に肺囊胞の最大 径の肋間で壁側胸膜を露出した。壁側胸膜と臓 側胸膜 (囊胞壁) を一緒に $4-0$ モノフィラメ ント糸でタバコ縫合をかけ，この中心部から囊 胞内に 22 Fr フォーレカテーテルを挿入し， ： ルーン内に注水し胸壁近くで固定した。.フォー レカテーテルは水封とした，気胸となったため に胸腔ドレナージを追加施行した。第 1 病日に 残存肺は再膨張性肺水腫となっていた（Fig. 1 
Table 1 Changes in pulmonary function in our cases.

\begin{tabular}{|c|c|c|c|c|}
\hline & & preoperation & after suction & postoperation \\
\hline \multirow{8}{*}{ Case 1} & $\mathrm{VC}(\mathrm{m} l)$ & 820 & 1410 & 1270 \\
\hline & $\mathrm{FEV}_{1.0}(\mathrm{~m} l)$ & 470 & 760 & 740 \\
\hline & Blood Gas Analysis & & & \\
\hline & $\mathrm{O}_{2}$ supply & $3 l$ & $2 l$ & $1 l$ \\
\hline & $\mathrm{pH}$ & 7.423 & 7.423 & 7.425 \\
\hline & $\mathrm{PcO}_{2}(\mathrm{mmHg})$ & 50.2 & 47.5 & 41.2 \\
\hline & $\mathrm{PO}_{2}(\mathrm{mmHg})$ & 81.8 & 82.1 & 76.4 \\
\hline & Hugh-Jones & $\mathrm{V}$ & III & III \\
\hline \multirow{8}{*}{ Case 2} & $\mathrm{VC}(\mathrm{m} l)$ & - & - & 2790 \\
\hline & $\mathrm{FEV}_{1.0}(\mathrm{~m} l)$ & - & - & 1230 \\
\hline & Blood Gas Analysis & & & \\
\hline & $\mathrm{O}_{2}$ supply & $5 l$ & $2 l$ & RA \\
\hline & $\mathrm{pH}$ & 7.311 & 7.502 & 7.416 \\
\hline & $\mathrm{PcO}_{2}(\mathrm{mmHg})$ & 62.6 & 32.3 & 34.0 \\
\hline & $\mathrm{Po}_{2}(\mathrm{mmHg})$ & 83.4 & 79.8 & 90.0 \\
\hline & Hugh-Jones & V & III & II \\
\hline
\end{tabular}

VC: Vital capacity, $\mathrm{FEV}_{1.0}$ : Forced vital capacity in 1 second, RA : Room air

c, d). しかし左横隔膜は上に凸となり呼吸状態 は改善した (Table 1). 第 1 病日よりフォーレ カテーテルは持続吸引器に接続し $-3 \mathrm{cmH}_{2} \mathrm{O}$ より吸引を開始した。吸引圧をー $20 \mathrm{cmH}_{2} \mathrm{O}$ ま で上昇させるとともにバルーン容量を減少させ た.

手 術：再膨張性肺水腫が軽快した11月25日 に手術を施行した. 第 6 胁間中腋窩線上より胸 腔鏡を挿入するとブラは舌区より発生して扔り, 上区は気腫性変化が著しかった，囊胞内吸引孔 の癒着があり，また広基性ブラで胸腔鏡下での 処理は困難であると判断された，腋窩に約 $5 \mathrm{~cm}$ の皮切で小開胸を追加した。癒着を剝離して, ブラを切開開放し正常肺部分に人工被覆材（吸 収性ポリグリコール酸フェルト）を用いて自動 縫合器をかけ, 肺囊胞切除を行った。手術時間 は2 時間26分であった。

術後経過：12月 3 日胸腔ドレーンを抜去し, 内科で呼吸リハビリテーションを行い 2 月 1 日 退院した. 胸部レントゲン写真では術後胸水を 認めるが，横隔膜は上に凸の型となった(Fig. 1 -e). 必要酸素は $1 \mathrm{l} / \mathrm{min}$ に減少し, 自覚症状も Hugh-Jones III 度に改善した（Table 1).

症例 $2: 60$ 歳, 男性.

契煙歴： 50 本 $\times 28$ 年.

既往歴：特記事項なし.

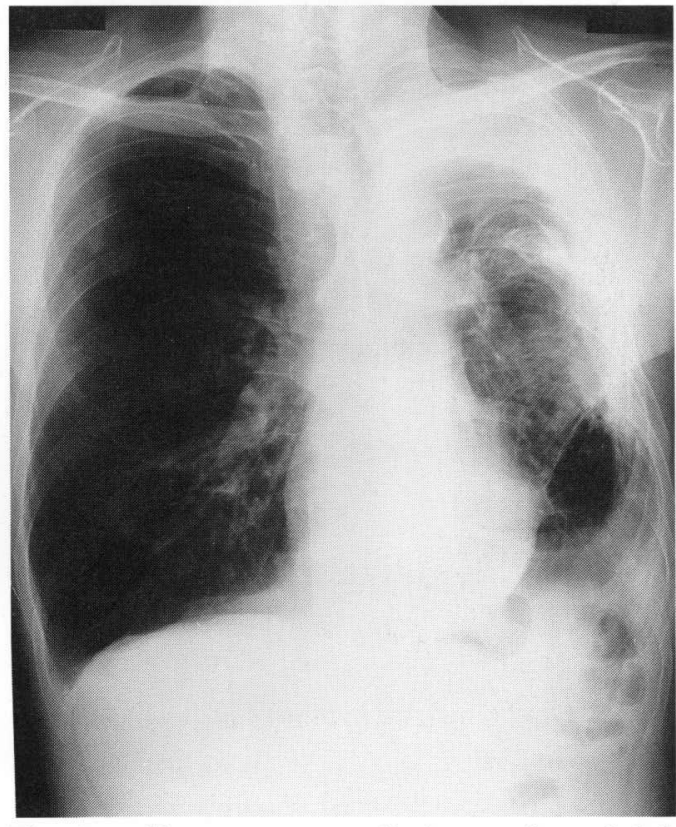

Fig. 1-e Chest $x$-ray at discharge showed left pleural effusion and elevation of left diaphragm.

現病歴：1991年ころから歩行時の息切れを自 覚し, 近医で巨大気腫性肺囊胞の診断で経過観 察されていた. 1998年暮れより，たびたび呼吸 器感染症に罹患するため当院を紹介受診した.

現 症：身長は $168 \mathrm{~cm}$ で体重は52 kg であ った. 呼吸は起座位で30回/分, 両側肺野で狭窄 
音を聴取した. Hugh-Jones V 度であった (Table 1).

入院時検査成績: 起座位で酸素 $5 \mathrm{l} / \mathrm{min}$ 吸 入下の動脈血ガス分析は, Table 1 に示した.

入院後経過：1999年 1 月 26 日に入院した. 入 院時胸部レントゲン写真では肺炎像は認められ なかった (Fig. 2-a). しかし喘息様発作と低酸
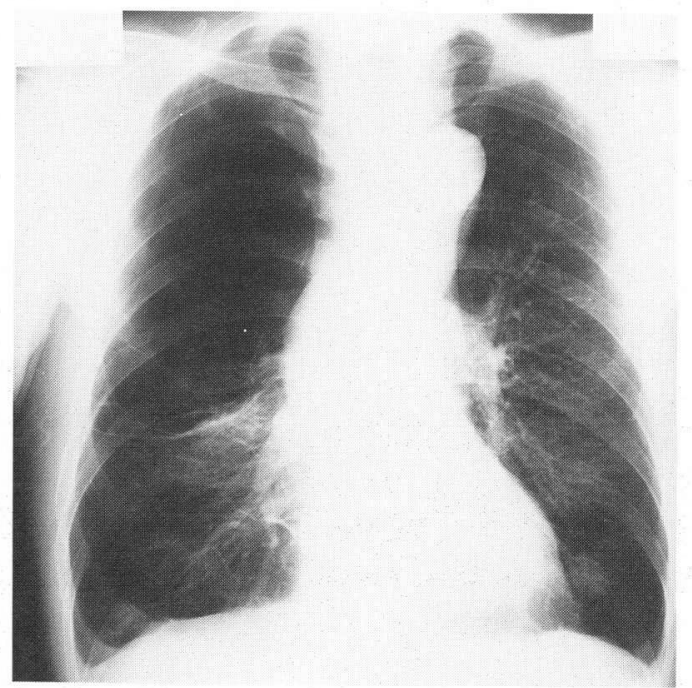

Fig. 2-a Chest $\mathrm{x}$-ray on admission showed giant emphysematous bulla in the right thoracic cavity.

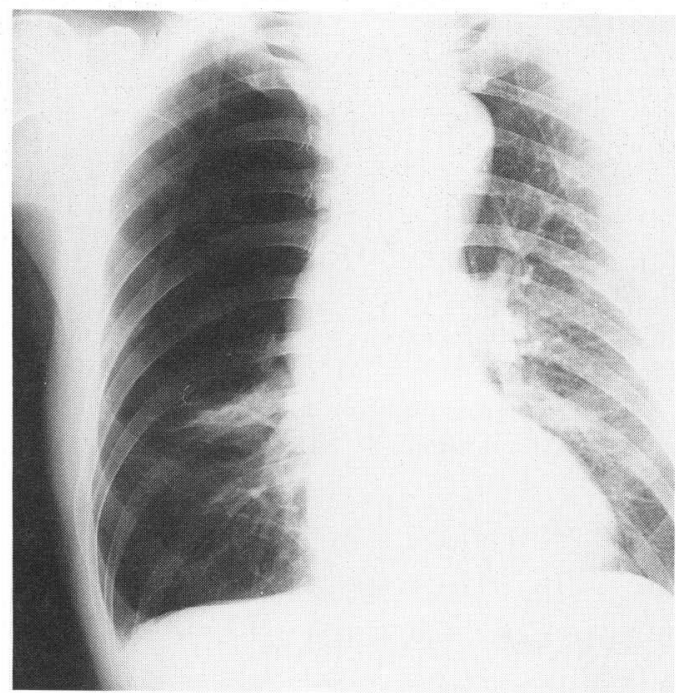

Fig. 2-b Chest $\mathrm{x}$-ray after 2 days on admission showed the flat and descent of the right diaphragm.
素血症がみられたため, 気管支拡張剤・ステロ イド（リンデロン $18 \mathrm{mg} /$ 日）及び酸素が投与さ れた。内科的治療にも拘わらず，呼吸状態は改 善せず，1月28日の胸部レントゲン写真では右 横隔膜の平低化が認められた (Fig. 2-b). 感染 あるいは喘息を契機としたチェックバルブ機構 が，ブラを巨大化させて呼吸状態の改善を妨げ ていると判断した， 1 月28日に症例 1 と同様の 手技で右肺囊胞内に 22 Fr フォーレカテーテル を留置し，水封として抢いた，同時に右胸腔ド レナージを施行した (Fig. 2-c). 肺囊胞内の減 圧により呼吸状態は速やかに改善した（Table 1).しかし, 右中葉に肺炎を併発した.

手 術：肺炎の軽快及びステロイドの減量を 待ち 2 月 24 に手術を施行した. 胸腔鏡を第 6 肋 間中腋窩線上から挿入した。ブラは右 $\mathrm{S}^{1}$ から $\mathrm{S}^{2}$ にかけて存在した. 癒着剝離と囊胞切除を容 易にするために小開胸を聴診三角に揖いた。ブ ラを開放し，自動縫合器にて囊胞切除を行った。 人工被覆材は使用しなかった。手術時間は 1 時 間12分であった。
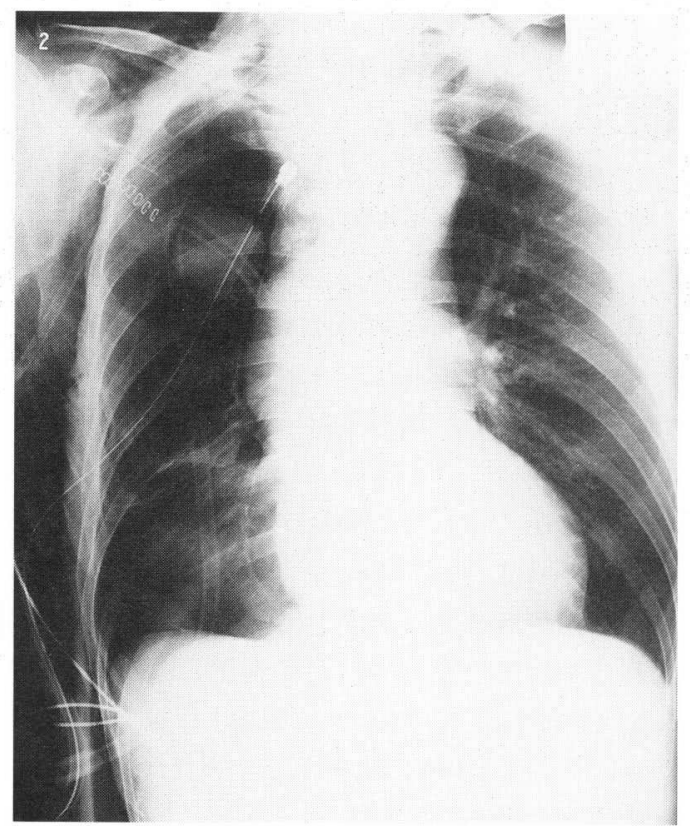

Fig. 2-c Chest $x$-ray showed elevation of the right diaphragm after suction of the giant emphysematous bulla. 


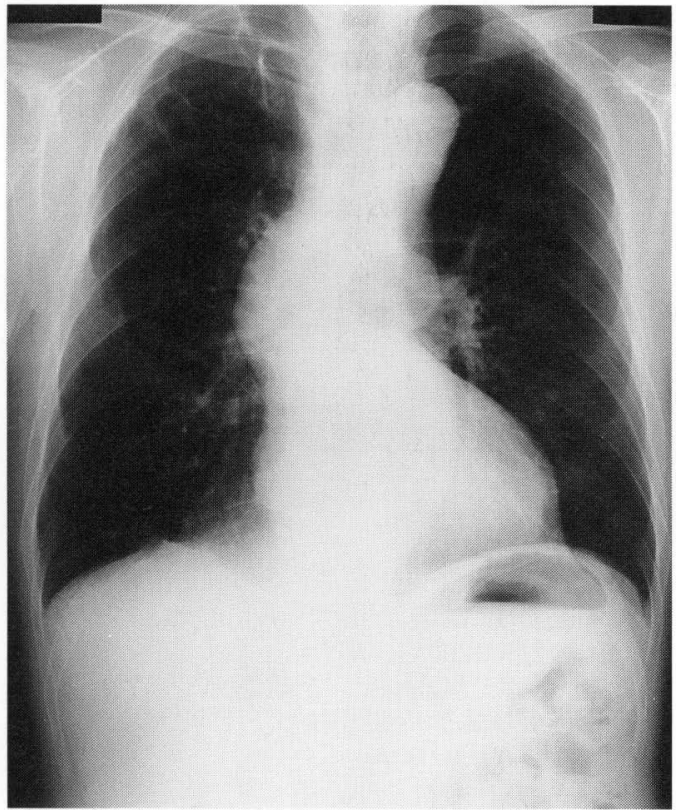

Fig. 2-d Chest $x$-ray at discharge showed elevation of right diaphragm.

術後経過： 3 月 3 日胸腔ドレーンを抜去し， 内科にて呼吸リハビリテーションを行い 4 月 15 日退院した. 胸部レントゲン写真で右横隔膜は 上に凸となっていた (Fig. 2-d). 呼吸困難は Hugh-Jones II 度に改善し, 酸素は不要となっ た (Table 1).

\section{考案}

巨大気腫性肺囊胞症（巨大ブラ）は一側胸腔 の三分の一以上を占めるブラと定義され，その 多くの症例で実質の気腫性変化を伴っている. 巨大ブラ患者には無症状例と有症状例が存在す るが，有症状例であっても，巨大ブラによる症 状か実質の変化（気腫性変化の程度）による症 状かの見極めは困難である ${ }^{11}$. 巨大ブラに対す る手術適応は1）増大傾向の認められるもの,

2) 圧排肺の存在が疑われるもの，3）呼吸器症 状を有するものとされている8). 巨大ブラは存 在するが，著しい低肺機能例は開胸手術の適応 となることはなかった。しかし，最近このよう な低肺機能例に肺囊胞内吸引療法を行うことで, 呼吸機能が改善することが報告されてきた ${ }^{2-7)}$.

囊胞内吸引療法は, ブラ内にドレナージチュ
ーブを留置し，吸引することによりブラの縮小 をはかり，呼吸状態の改善を目指寸治療方法で ある ${ }^{9}$. ブラが単房性であること帛が，この治療 法のよい適応とされている。ささらにわれわれは 胸腔内に癒着が予想され, 残存肺の存在しない 症例ではブラの縮小が得られないため，また気 管支との間に大きな交通がある場合には充分に ブラ内を減圧できないことが予想されるため囊 胞内吸引療法の適応とは考えていない.

囊胞内吸引療法に引き続く治療は, ブラ内に 癒着促進剤を注入する保存的治療法と開胸手術 を施行する外科治療法が報告されている. 本邦 の報告例の多くは保存的治療法であり, Uyama $ら^{2)}$ は囊胞内吸引後に癒着促進剂を注入するこ とで，大泉ら ${ }^{3)}$ は気管支塞栓術を併用すること で積極的に囊胞縮小を促す治療を報告した。 こ の治療方法は, 全身麻酔下の開胸手術の必要が ないので，特に低肺機能患者に有効であり，そ の利点としては, 局所麻酔でできる, 胸壁損傷 が少ない，隣接肺の損傷がないなどの点が挙げ られている3 ${ }^{3}$. 外科治療法は肺囊胞内吸引療法

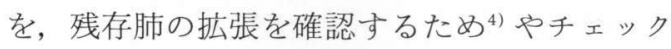
バルブ機構に伴ら拡張ブラの減圧をはかるた め7)に施行している報告がみられる(Table 2). 我々の経験した 2 症例は, 囊胞内吸引により 呼吸状態は改善し, 開胸手術を施行し得た。呼 吸状態の改善がなければ, 癒着促進剂の注入が 考慮された. しかし汎用される癒着促進剤の中 には気管支に注入された際の局所刺激性を懸念 する報告 ${ }^{5)}$ や，頻回に癒着促進剂の注入を要す る症例6) も報告されている. したがって当科で は, 基本的には呼吸状態の改善された症例では, 開胸手術の適応としている。これまでは低肺機 能患者に呼吸筋の損傷を伴う開胸手術を施行す ることの侵襲の大きさ ${ }^{11)}$ や, 術後合併症の発生 を危惧し，開胸術の対象とする事が躊躇された と考光られる. しかし自動縫合器の進歩, 手術 に際しての胸腔鏡の使用 ${ }^{12)}$ や開胸方法の工夫 ${ }^{2)}$ により，より低侵襲な手術が可能となっている

(Table 2). 本 2 症例はいずれも広基性のブラ であり囊胞切除線の決定が困難であったことや, 自動縫合器の使用本数が多くなることを考慮し 
Table 2 Reports of surgical treatment after intracavitary suction for giant bulla.

\begin{tabular}{|c|c|c|c|c|c|c|}
\hline $\begin{array}{l}\text { Author } \\
(y r)\end{array}$ & Age & Sex & $\begin{array}{l}\text { Purpose of } \\
\text { suction }\end{array}$ & $\begin{array}{c}\text { Preoprative } \\
\text { suction (days) }\end{array}$ & Complication & $\begin{array}{c}\text { Skin } \\
\text { incision }\end{array}$ \\
\hline $\begin{array}{l}\text { Yoshiya } \\
\text { (1994) }\end{array}$ & 49 & $\mathrm{M}$ & re-expansion & 21 & none & auscular \\
\hline $\begin{array}{l}\text { Inoue } \\
\text { (1999) }\end{array}$ & 60 & $\mathrm{~F}$ & decompression & 6 & none & axillar \\
\hline case 1 & 60 & $\mathrm{M}$ & re-expansion & 36 & $\begin{array}{l}\text { re-expansion } \\
\text { pulmonary edema }\end{array}$ & $\begin{array}{l}\text { VATS } \\
\text { axillar }\end{array}$ \\
\hline case 2 & 60 & $\mathrm{M}$ & decompression & 27 & pneumonia & $\begin{array}{l}\text { VATS } \\
\text { auscular }\end{array}$ \\
\hline
\end{tabular}

VATS : Video-assisted Thoracic Surgery

小開胸を行った. 胸腔鏡を併用することで開胸 創を通常より縮小できる利点があった。このた め, 術後創痛も少なく, 排痰困難や肺炎などの 肺合併症を併発することも無く, 自覚症状も速 やかに改善した（Table 1).

当科で経験した症例 1 は, 再膨張性肺水腫を 合併したために, 症例 2 は肺炎のために開胸ブ ラ切除が遅れた。症例 1 では吉谷ら ${ }^{4)}$ が述べて いるように平圧から徐々に吸引圧をあげるなど， ドレーン管理を工夫することにより, 症例 2 で はブラのサイズ変化と呼吸状態を経時的に観察 し，これらに因果関係があると判断されたとさ に直ちに囊胞内吸引を行らことで開胸術前の長 期間ドレナージは防ぎ得たと思われる（Table 2). 囊胞内吸引療法は癒着療法や開胸術の前段 階の治療であり, 囊胞内吸引段階での合併症の 発生はできうる限りさけるべきものと考兄られ た.

\section{結 語}

巨大気腫性肺裳胞による重症呼吸不全患者に 対する塞胞内吸引療法は有効であった。呼吸状 態の改善後に安全に胸腔鏡併用小開胸手術を施 行し得た.

\section{文献}

1) 渡辺洋宇, 藤村重文, 加藤治文: 臨床呼吸器外 科 1 版, 194-197, 医学書院, 東京, 1995.

2) Uyama T, Monden $Y$, Harada K, et al :
Drainage of giant bulla with balloon catheter using chemical irritant and fibrin glue. Chest 94: 1289-1290, 1988.

3）大泉弘幸, 藤島 丈, 正岡俊明, 他：巨大ブラ に対する襄胞内吸引療法, 日胸外会誌 41 : 1502-1505, 1993.

4）吉谷克雄, 名村 理, 青木英一郎, 他: 襄胞内 吸引により残存肺再膨張後, 手術した巨大気腫

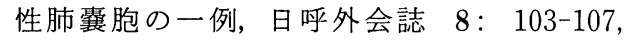
1994.

5) 中村清一, 松村 啓, 橋本恭士, 他: 気管支喘 息に合併した巨大ブラに対するブラ内吸引㦄 着療法, 日胸疾会誌 32:1115-1119, 1994.

6）吉谷克雄, 富樫賢一, 佐藤良智：塵肺症を伴 う

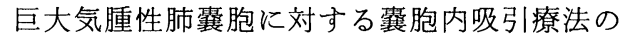
一例, 胸部外科 $49: 783-785,1996$.

7）井上修平, 藤野昇三, 手塚則明, 他：急速に増 大した右巨大肺囊胞の 1 切除例, 日呼外会誌 13: 545-550, 1999.

8) Wesley JR, McLead WM, Mullard KS: Evaluation and surgery of bullous emphysema. J Thorac Cardiovasc Surg 63: 945, 1972.

9) Macarthur AM, Fountain SW : Intracavity suction and drainage in treatment of emphysematous bullae. Thorax 32: 668-672, 1977.

10）大泉弘幸, 星 永進, 青山克彦, 他：巨大気腫 性肺囊胞症の外科治療一術式及び周術期管理 一, 日呼外会誌 4:437-443, 1990.

11) Entwistle MD, Roe PG, Sapsford DJ, et al : Patterns of oxygenation after thoracotomy. Br J Anesth 67 : 704-11, 1991.

12) Menconi GF, Melfi FMA, Mussi A, et al: Treatment by VATS of giant bullous emphysema : results. European J Cardio-thorac Surg 13:66-70, 1998. 


\section{Two cases of bullectomy by VATS for emphysematous giant bulla after intracavitary suction}

\section{Tadashi Aoki, Tatsuhiko Hirono}

Department of Pulmonary Surgery, National Nishi Niigata Chuou Hospital, Niigata, Japan

In two cases with severe dyspnea, chest $\mathrm{CT}$ revealed emphysematous giant bulla occupying half or more of the hemithorax. We performed the intracavitary suction for the purpose of expansion of compressed normal lung and decompression for giant bulla. Intracavitary suction provided significant clinical improvement in each case. Bullectomy by VATS were performed safely under general anesthesia. There were no postoperative complications. Intracavitary suction of emphysematous giant bulla is a safe and effective modality before VATS bullectomy. 